\title{
Akbar or Aurangzeb? Ethics, Empire, and Print Publics in Colonial India
}

\author{
LEIGH DENAULT \\ E-mail:1td22@cam.ac.uk
}

In the 1870s, Indian news editors warned their readers of a series of crises threatening India. They saw the famines, wars, and poverty that they were describing as symptoms of the same illness: Colonial governors had failed to implement an ethical system of governance, and had therefore failed to create a healthy body politic, choosing to expend energy in punishing or censoring dissent when they should have been constructing more durable civic institutions. In North India, earlier Mughal traditions of political philosophy and governance offered a template to critique the current state. In drawing on these traditions, editors linked multiple registers of dissent, from simple 'fables' about emperors to more sophisticated arguments drawn from newly reinterpreted akhlaq texts, creating a print record of the multilingual, multivalent literary and oral worlds of Indian political thought. The figures of the Mughal emperors Akbar and Aurangzeb, representing the zenith and nadir of Mughal sovereignty, in turn linked popular and learned discussions on statecraft, good governance, and personal responsibility in an age of crisis. The press itself became a meeting point for multivalent discourses connecting South Asian publics, oral and literate, in their exploration of the nature of just rule in the context of empire, calling, in the process, new 'publics' into being.

Keywords: colonial newspapers, sovereignty, public spheres, print publics, colonial India

\section{Introduction: Indian News as an Imperial Crisis}

Famine has been constantly raging in India for some years past (...) Nothing will avail to secure India against famine until the Government heartily wishes for the well-being of the people. When we compare the present time to that of the Mughal emperors, like Akbar, we find the difference between the two as great as between a shell and a gold mohar (...) The people even now remember the emperors of the Mughal dynasty, because each of them was better than the other. But Aurangzeb alienated the hearts of the Hindus, and thus accelerated the overthrow of Muhammadan supremacy. ${ }^{1}$

In 1877, a thirty-three-year-old Sanskrit teacher in Allahabad helped to launch a periodical in Hindi, after collecting subscriptions through a literary society. ${ }^{2}$ When the 
Vernacular Press Act of 1878 was passed, shortly after the first issue was produced, the other members ended their involvement, leaving the teacher, Balkrishna Bhatt, as sole editor. ${ }^{3}$ Bhatt's Hindi Pradip, a monthly newsmagazine, would remain widely respected for its critical essays on a host of topics of the day, as well as its experimentation with more accessible forms of language and literary criticism. ${ }^{4}$ The magazine would last until 1910, when both the Pradip's revolutionary-nationalist stance and new anti-sedition legislation meant that even radicals were no longer willing to take on the risk of printing it. $^{5}$ Although Bhatt was part of an important Hindi and Sanskrit literary group forged by Bhartendu Harishchandra, ${ }^{6}$ and an author as well as a scholar, ${ }^{7}$ he did not own his own press. $^{8}$ He had failed his university entrance exams, which barred his path to more remunerative work, and had a contentious relationship with his family, which ended in a complete severing of ties. He funded the printing of Pradip and his other projects through his teacher's salary as well as by working as an astrologer and practitioner of traditional medicine. 9 Bhatt was continually economising: one contemporary wrote that "the man who edited a paper for 28 years did not write a single line on a blank sheet. All his articles were originally written on the back of examinee's books or on used-up newspapers." 10

Balkrishna Bhatt was at the centre of literary and political groups associated with the emergence of a specifically Hindu cultural nationalism, but his life and work are reminders of the continuing influence of cosmopolitan Persianate culture across nineteenthcentury northern India. ${ }^{11}$ Pandit Madan Mohan Malaviya, who wrote for Bhatt's Pradip as a young man, would go on to become president of the Indian National Congress Party, as well as founder of the Akhil Bharat Hindu Mahasabha and Benares Hindu University. ${ }^{12}$ Bhatt was identified early on as antigovernment; when he was robbed and beaten, colonial authorities delighted in his misfortune. ${ }^{13}$ Bhatt would lose his job in 1908, after delivering a fiery speech protesting the imprisonment of Bal Gangadhar Tilak, ${ }^{14}$ whose promotion of the Hindu Ganesh festival as a means of uniting the "bourgeois" public with the "public arenas" of the streets became central to a new mode of nationalism in the late nineteenth and early twentieth centuries. ${ }^{15}$ But Bhatt was also a part of a "middling class" enabled by a late Mughal Persianate cosmopolis, and was a product of that world as much as of the British colonial era. And in the late 1870s, Bhatt did not advocate an end to empire as the solution to India's ills, but rather demanded accountability and fairness from British rulers. In his editorial on 1 July 1878, Bhatt wrote approvingly of India's Muslim past and of Mughal administration, depicting an Indian golden age under Akbar, while comparing British colonial rule with the emperor most popularly associated with Mughal decline, Aurangzeb.

Bhatt was not alone in his references to Akbar and Aurangzeb amid the crises of the 1870s. This tale of two emperors had become a widely understood social text which editors self-consciously deployed to bridge multiple, and often competing, discourses on the relationship between sovereign and subject, and on the just ordering of state and society. Stories of Akbar and Aurangzeb functioned across sociopolitical registers: they could reference akhlaqi (ethical or moral) traditions, ${ }^{16}$ or provide a space for dialogue with European retellings of Indian history, ${ }^{17}$ or make appeals to a popular collective memory. As Farina Mir has suggested of the Punjabi Hir-Ranjha epic that moved across multiple 
genres and registers over the centuries, ${ }^{18}$ I will argue that stories of Mughal rulers circulating through the Indian-language press provided a sociocultural meeting place, but also a shared political language that linked older "templates of justice"19 with nineteenthcentury understandings of the public good. ${ }^{20}$

The nineteenth-century Indian print world that Bhatt entered in the 1870 s was a site of experimentation with new genres and new ways of integrating news and entertainment, both to sell copy and to shape public opinion. Indian papers were, like many early newspapers worldwide, highly diverse containers. They featured editorials, republished manuscript texts deemed classic or improving, published humour and satire, translations, dramas, poetry and dialogues, reprints from other periodicals, letters, and of course, news. Indian journalism developed its own visual languages, incorporating aesthetics drawn from manuscript culture and innovating on new forms such as political cartoons. ${ }^{21}$ Long-standing manuscript and oral traditions which had connected South Asia to a broader European as well as Islamic world of texts and ideas were linked to imperial and global networks opened by "steam and print." 22 While diverse, and often divided, India's print publics shared a high degree of interpenetration and interdependence, constituting "critical," rather than simply "representative," publics and counterpublics in the decades before the emergence of revolutionary nationalism. ${ }^{23}$

In this essay, I will focus on the 1870s, a period that saw the emergence of new newspapers like Bhatt's Hindi Pradip, as well as new discussions on the nature of empire and just rule that revisited the Mughal past while questioning the geopolitics of the colonial present. The 1860s had seen an expansion of presses in operation, as well as increasing surveillance by the colonial state, which had begun to attempt to monitor and control Indian-language publication in the wake of a series of imperial crises. ${ }^{24}$ During the Great Eastern Crisis of 1875-78, a series of uprisings and wars in the Ottoman Balkans followed by the Russo-Turkish war (1877-78) and Second Anglo-Afghan war (1878-80) had led to widespread concern across India about British foreign policy. ${ }^{25}$ The Great Rebellion of 1857 was a recent memory, and transformations in colonial governance in India had accompanied the escalation of devastating famines, leading Indian editors to link the lack of humanitarian aid for Ottoman allies with the paucity of relief efforts for those starving in India.

Colonial officials were late to understand the capacity and potential of Indian journalism, and ultimately responded to an increasingly critical Indian press by imposing a draconian censorship regime. Ironically, the same technologies of print which allowed the easy mass distribution and dissemination of new ideas made those ideas easier for governments to censor and monitor. Translators had been hired to read through the Indian papers in each province and to make a report on items of interest to the government. ${ }^{26}$ But the sheer volume of information meant that by the 1860 s the Indian press and communication by post or other social networks was "increasingly out of government control." 27 Legislative attempts to silence Indian print in the $1860 \mathrm{~s}$ and $1870 \mathrm{~s}$, and to suppress dissent more broadly through the Dramatic Performances Act of $1876,{ }^{28}$ however, would instead reveal the depth and strength of new Indian "publics" across the nineteenth century. ${ }^{29}$ 
That the Great Eastern Crisis and Indian print responses became a crisis for British governance in India provides insight into how mid-nineteenth-century news was produced, circulated, and received by Indian publics. Focussing on responses within northern India, but incorporating transregional and global debates and exchanges, I will argue that reporting on international, imperial, and frontier news shaped both interactions with colonial censorship regimes and imperial policy, but also drew upon and brought into novel conceptual frames ideas such as tyranny $(z u l m)$ and liberty (azadi/swatantra), justice and the rule of law (adal/kanoon), the public or common good/welfare (rifah-e am), the nature of loyalty (wafaadaar), and the duties of the citizen (shehri) and state (hakumat/sarkar). I will consider how deliberate misreadings of colonial policy and global politics, which took obviously hypocritical rhetoric at face value in order to subvert it, point to, in Sukanya Banerjee's words, the creation of new "cognitive maps" and "temporalities" through the medium of the newspaper press. ${ }^{30}$ Newspapers began to rework conceptions of just imperial rule across multiple traditions of political thought, producing analyses that were simultaneously parochial and cosmopolitan, ${ }^{31}$ relying on the circulation of ideas through new print publics which connected and expanded, rather than replacing, older patterns of textual and oral transmission.

\section{Defining the Press and Its Publics in Colonial India}

Whether or not colonial India could be seen to possess a "public sphere" has been a contested historiographical point. Sir Bartle Frere began an 1871 lecture to the East India Society, to an audience that included Dadabhai Naoroji, by stating that the question, "Is there such a thing as a public opinion in India?" was generally asked in a way to presuppose a negative answer. ${ }^{32}$ Frere himself believed that "published opinion," as distinct from "public opinion," represented only a tiny fraction of Indian society. While he felt that "public opinion" did exist—defining it as "any opinion which is not personal nor peculiar, and which is shared and more or less expressed by large bodies of men"he believed that it was "less articulate" than that of England, due to lower levels of general education and literacy.

Assumptions similar to Frere's underpinned much colonial policy, but were not reflective of South Asian realities. Practices of collective reading and the coexistence of print with vibrant oral and manuscript cultures allowed literate and nonliterate groups to communicate across both geographic and class boundaries in nineteenth-century South Asia. ${ }^{33}$ The conventions and aesthetics of manuscript texts continued to provide templates for printed Indian books and newspapers. Abdul Halim Sharar wrote that the printers of Lucknow excelled at producing kitabe (books) on the finest quality paper, employing the best calligraphers trained in producing manuscripts for more elite patrons, and providing their skilled artisans with every resource available. ${ }^{34}$ Manuscript and oral traditions were in turn transformed via contact with the new audiences reachable through print.

Because they also remained rooted in older oral cultures and continued to move within oral communication networks, mid-nineteenth-century periodicals circulated far beyond the number of physical copies produced. George Birdwood, a member of the colonial 
medical service who had grown up in India, noted that how Indian papers were experienced by readers, and listeners, transformed their impact and significance: "Take for instance the Indu Prakash. One copy of that would represent far more in India than one copy of any paper in this country. It was taken to the Temple-tank and read at night by moonlight after the people came from their work. Every word of it was read as few papers were here. ${ }^{35}$ The global processes which reintroduced print to India would ultimately create newly interconnected, multilingual, and overlapping publics, breaking into worlds of learning formerly dominated by manuscript cultures, which were then brought into conversation with popular oral genres, rumour, telegraph news, and everyday concerns. ${ }^{36} \mathrm{New}$ concepts were introduced, such as the idea of the "public" itself, ${ }^{37}$ while older ones were renovated or revisited.

The rise of colonial Indian print was both a "revolutionary" and an "evolutionary" process. In northern India, lithography, or chemical printing, rather than moveable type print, became the medium of mass print, a factor shared with a broader Persianate world of letters that connected North Indian Urdu publics to Arabic-script publics around the world. ${ }^{38}$ This expansion of print had therefore started before the introduction of telegraphy and new government education initiatives after $1857 .{ }^{39}$ Until 1857, colonial governors had themselves relied on a Mughal system of accredited news-writers (akhbar nawis) for intelligence on royal and princely courts across South Asia, and were therefore aware of the Persianate tradition of akhbarat, widely circulated newsletters produced by these professional reporters, who served as both diplomatic correspondents and journalists. ${ }^{40}$

Yet despite a peripheral awareness of thriving Indian-language modes of social and cultural communication, colonial observers often took credit for the development of Indian print publics, depicting Indian society as lacking in civic spirit. ${ }^{41}$ Early usages of the English term "public" during the nineteenth century, and later efforts by Indian intellectuals and writers to enter into dialogue with European discourses on the "public good" and "public opinion," which have recently been reevaluated, ${ }^{42}$ tended previously to be viewed as supporting arguments that "the public" was a Western transplant. ${ }^{43}$ In addition to calls for understanding liberalism as developing globally through debates and exchanges with intellectuals in the colonial world, ${ }^{44}$ scholars of Mughal and early colonial India have also found substantive evidence of "vibrant spheres of publicity," 45 and of South Asian forms analogous to Western "public spheres," which both predated British rule and the rise of global liberal discourses, and continued to operate alongside, within, and through "colonialism and its forms of knowledge.",46

While some studies of the "public" in South Asia countered early official narratives, pointing to flourishing public spheres operating during this period, ${ }^{47}$ others have instead emphasised the splintered nature of colonial Indian publics, highlighting linguistic, religious, social, and regional divisions which undercut the potential for a "national" public. ${ }^{48}$ More recently, historians have challenged public sphere scholarship that posits South Asia as a "special case," instead pointing to the extent to which "the public" must always be seen as an "unstable assemblage of shifting ideas and institutions, defined as much by its internal contradictions as by its normative force," 49 and as a "category of interpretation" rather than an "empirical object." ${ }^{50}$ It is this definition that this essay will adopt. 
As Neeladri Bhattacharya notes, even in the later nineteenth and early twentieth centuries, "the national public and community publics were not entirely segregated, opposed and hostile to each other; they were intertwined in complex ways." ${ }^{51}$ Linguistic and religious communities did not define exclusivist print publics in the 1860s and 1870s, and exclusivist movements tended to be exceptional, and relatively marginal, during this period. ${ }^{52}$ Editors of $\mathrm{Urdu}^{53}$ papers of the mid- to late nineteenth century were not necessarily Muslim, nor did they imagine their reading publics to be majority Muslim: Urdu was an official language of government in the North-Western Provinces, and "Urdu" was often used interchangeably with "Hindustani," a language written in the Urdu script but capacious in its vocabulary and registers, linking a number of spoken and print cultures across colonial India. ${ }^{54}$ Similarly, while there is much evidence of lawyers and judges who became active as editors and publishers, as well as instrumental in civic associations and, later, Indian nationalist organisations, the majority of presses and periodicals that emerged during the nineteenth century were not run by lawyers but by a "middle layer" of Indian society whose own claim to social status was continually called into question by both colonial and Indian observers. ${ }^{55}$

Newspaper editors and audiences of the 1870s constructed new genres and new spaces for sociopolitical imaginings that both deliberately drew from a precolonial past and made use of innovative colonial vehicles to connect to audiences in diverse sites and circumstances. Bhattacharya's narrative is useful in understanding the ultimate emergence of powerful communal interests in Indian public life, particularly from the early twentieth century, when linguistic and community movements reinforced and revived exclusivist imaginings of personhood, public space, and the nation. But these social fault lines developed through contingent historical processes, rather than constituting a universal characteristic of the Indian-language press or indeed Indian society. Perhaps no modern public can truly lay claim to being "singular and unitary, constituted of individuals who come together as anonymous beings whose social moorings were irrelevant, as equivalent citizens." tions that sustained colonial Indian-language presses were not overtly political, although they could begin to delineate cultural groupings which would later become politicised. ${ }^{57}$ Ritu Khanduri has highlighted the extent to which colonial officials tended to see, by the mid-nineteenth century, "impertinence" as a specialism of the Indian-language press, which was not subtle in its critiques of power, nor in its use of humour and satire to counter colonial absolutism. ${ }^{58}$ What the colonial state cast as a space of "sedition" was in fact a space of playfulness and irreverence, where any subject matter was fair game: especially the business of princes, sultans, and emperors. ${ }^{59}$

\section{"A Shell and a Gold Mohar": Ritual, Sovereignty, and Substance}

The political context of the 1870 s, which invited editorial comment on topics from the Eastern Crisis and the famines to debates over taxation ${ }^{60}$ and the 1878 Vernacular Press Act, framed the Indian press's fixation on sovereignty, rights, and empire. In his editorial 
on 1 July 1878, Bhatt wrote, "When we compare the present time to that of the Mughal emperors, like Akbar, we find the difference between the two as great in between as a shell and a gold mohar." The "Delhi kings" [he used the term Badshah], he wrote, did not overtax their subjects, and famines were "rare in their times," nor did the Mughals discriminate between Hindu and Muslim in appointments to public service, their legal system being equally impartial. "But the times have now quite changed," Bhatt noted, and the most an Indian might hope for is to be "allowed to work at the office tread-mill," i.e., be assigned menial office work, but never be placed in a position of trust, authority, or responsibility. On land management and the famines, Bhatt argued that the Mughals had left large tracts of land uncultivated and allowed anyone to graze animals or gather resources from them; the British had left "no tract of land" unaccounted for in their taxation scheme, and were only there to "amass riches," uncaring whether people starve or thrive. Bhatt concluded:

The people even now remember the emperors of the Mughal dynasty, because each of them was better than the other. But Aurangzeb had alienated the hearts of the Hindus, and thus accelerated the overthrow of Muhammadan supremacy in India. The rule of India then passed into the hands of Marathas. But they could not properly conduct the administration. When Heaven perceived that they could not properly protect the lives and property of the people, it pleased Him to entrust the reins of the Government into the hands of the British. ${ }^{61}$

Balkrishna Bhatt's 1878 essay was far from exceptional in its references to the "good" kings of Delhi. Through both late Mughal Persianate histories and debates on India's past and present in the colonial period, two Mughal emperors had come to represent the zenith and nadir, respectively, of just imperial governance: Akbar (r. 1556-1605) and Aurangzeb (r. 1658-1707). The few studies which have examined the significance of invocations of Akbar or Aurangzeb in Indian writing have focused on English-language writing, ${ }^{62}$ but Akbar and Aurangzeb were also regularly referenced in Indian-language newspaper editorials and essays on the nature of governance and empire, just rule and tyranny, from the 1820 s onwards.

South Asian conceptions of imperial sovereignty interacted with new British forms in the pages of the papers. Discussions in Indian-language newspapers on tyranny were often framed as attempts to educate readers, including colonial officials, on the nature of good governance: to apply the ethics of akhlaq and to bring the lessons of both imperial histories and of contemporary global politics into conversation with debates about British rule in India. Indian liberal Rammohan Roy, for example, saw Akbar's policies as consonant with, and inspirational for, liberal empire in the nineteenth century, and advised that the systems of petitioning authority and the office of the Mughal newswriters (akhbar nawis) be revived under British rule, while in his Persian paper he emphasised the importance of the state in providing space and resources for the development of civil society. ${ }^{63}$

Akbar's policies were generally admired by both British and Indian historians and writers of the nineteenth century, even by critics of Mughal rule more generally, while Aurangzeb in turn was almost universally vilified. Early Orientalist writers in particular 
celebrated Akbar's court, perhaps, as Phiroze Vasunia argues, because "he achieved more or less what they themselves were hoping to achieve during their own rule: control and command of the subcontinent through a deep knowledge of its people no less than through political and military exploits." ${ }^{, 64}$ Understanding just rule and tyranny in reference to Mughal rule was a common theme for newspaper writers from the $1850 \mathrm{~s}$; in 1853, Imdad Hussain, then editor of the Delhi Urdu Akhbar, had emphasised the moral duty of the editor as a spiritual leader and teacher to the truth, to himself, and to his public, using Mughal models of leadership and rulership. ${ }^{65}$ The Hindoo Patriot ran a series of ten articles comparing the Mughal and the British empire in $1854 .^{66}$ For newspaper editors of the $1870 \mathrm{~s}$, in their attempt both to educate colonial rulers in Indian political philosophy and to find a shared language to convey their critique of contemporary British rule, Akbar could be summoned as an example of a "foreign" ruler whose ethic of statecraft had stabilised and perpetuated Mughal authority. By invoking Akbar as an ideal emperor of a multiethnic polity, editors could both appeal to a shared historical assessment of his period in power and introduce a fundamental critique of British governance.

Bhatt's warning referenced Perseo-Arabic akhlaqi texts on divine kingship which placed the emperor as the "shadow of God." In Shajara, on the obligation of the temporal ruler to embody justice, Fakhr-i Mudabbir (c. 1157-1236) states: "The shadow consists of care and tranquillity because justice and security are found there, and in the shelter and protection of kings there is a resting place for the oppressed and refuge from the oppressors. ${ }^{, 67}$ In Mughal India, conceptions of sovereignty had structured and sustained a public sphere simultaneously performative and critical. ${ }^{68}$ Akhlaqi discourses had flourished during the late Mughal period, when new successor-state regimes sought to legitimate their own authority by asserting the Mughal centre had transgressed its own "moral political boundaries." 69

Indian writers, and listeners, did not have to be classically trained, however, to access akhlaqi discourses and debates. The nineteenth century saw numerous new editions of classic texts on moral philosophy and education, such as Nasir ud Din Tusi's Akhlaq-e Nasiri and Akhlaq-e Jalali by Jalal ud Din Dawani, which emphasised the importance of virtuous behaviour for rulers in regulating systems of governance at the level of both household and state, while simultaneously reinterpreting those ideals for a modern readership. ${ }^{70}$ Edited versions of these texts excerpted key passages and added explanatory comments, aiming to make them accessible to a wider audience. Akhlaqs were among the first Persian and Urdu books to be printed in the early nineteenth century, and remained in print through the twentieth century. ${ }^{71}$

The 1870s in particular witnessed a boom in the printing of vernacular translations of akhlaqs, as well as texts which aimed to distil or summarise their contents for younger readers. This was in part spurred by new government education department initiatives, and in part by the broader expansion of book printing and textbook printing across India. Avrill Powell's work on Indian-language texts on ethics used in educational curricula across the nineteenth century suggests that a core body of akhlaqi material which had been defined during the Mughal period first as part of a princely or elite 
education, and later as appropriate schoolroom material, remained widely circulated through both colonial and indigenous schools throughout the nineteenth century. ${ }^{72}$

Akhlaq texts brought in multiple traditions and perspectives, drawing on Aristotle as well as Arabic and Persian exemplars, intersecting with a Sanskrit moral educational tradition, ${ }^{73}$ and their wide circulation contributed to a common political vocabulary across the Islamic world. ${ }^{74}$ The terms and concepts used to understand barbarity and civilisation in these discourses provide a crucial context for how North Indian editors, schooled in an akhlaqi tradition, framed their assessments of society, politics, empire, just rule, and moral behaviour. Barbarity was marked, in these texts, by qualities such as being stone-hearted (sang-dil), merciless (be-rahm), and without compassion (be-dard), qualities forged by ignorance (jihalat). The Hindi concept of sabhyata (civilisation) similarly encompassed cultural, scientific, political, and social reform, as well as individual self-cultivation and self-control as components of both "civility" and civilising projects aiming at achieving unnati (progress) or sudhar (reform). ${ }^{75}$ In the akhlaq texts, and in Hindi discourses of social and self improvement, "civilisation is thus the creation of a virtuous self," 76 and compassion, hamdard, which according to Pernau constituted a "central emotion actively linking civilisation at the individual and national level: any person whose heart is affected by the plight of the nation as if it were his own, will cultivate the virtues and emotions which make for the nation's well-being, and work at civilising himself and improving others." 77 In the Urdu literature in particular, akhlaqi traditions focused on the perfection of the virtuous self as a step towards the creation of a just society, with the virtue of the sovereign anchoring a broader social well-being.

A. Azfar Moin has recently directed attention to the centrality of the extrapolitical in Mughal conceptions of sovereign authority, and of the Mughal emperor as a mediating body between heavenly and earthly powers, or between "millennial" time and historical time. ${ }^{78}$ Mughal political culture relied on a deep-rooted institutional frame, sometimes entangled with pre-existing systems for administration, which rendered its territory legible to a paper-based bureaucracy; it also foregrounded personal loyalty and rituals that physically marked or anchored subjects within an imperial body politic as well as within a shared moral landscape and cosmology. While Mughal kingship was rooted in Islamic thought and belief, it also, particularly as articulated under Akbar, claimed to transcend any singular religious practice or community. And Mughal political authority, the projection of their worldly power, as David Gilmartin has argued, rendered these "cosmic claims compelling for wide populations.",79

Newspaper essays drew on a popularised akhlaqi tradition to blend liberal critiques of absolutism with Mughal conceptions of the divine and popular mandate of kings. Discourses on Mughal sovereign authority were not, as the point about Mughal successor-state usage suggests, directed exclusively towards British rulers. Bhatt's Hindi Pradip mocked the lavish lifestyles of Indian princes in much the same vein that he decried the venality of British civil servants, only in India to amass wealth. ${ }^{80}$ The Nizam-ul Akhbar, noting that it had been founded on the birthday of the Nizam of Hyderabad and named after him, referenced these connections to solicit subscriptions 
and funding from "the nobility and gentry of Hyderabad," and to chastise them for their lack of patronage. ${ }^{81}$ Articles on the topic of British India, however, tended to attempt to explain the sociopolitical significance of these rituals, deliberately constructing, rather than simply referencing, shared social texts.

Indian editors explicitly referenced Mughal rituals that sustained both immediate social order and balance and provided a broader sense of cosmological balance, connecting the health and happiness of the population to divine approbation for the state of the empire. Balkrishna Bhatt wrote that the Mughal emperors "were weighed against jewels and precious metals on the days of the anniversary of their birth, which were distributed among the poor," while "none except the Government servants know when the day of the anniversary of Her Majesty's birth comes and goes." ${ }^{, 82}$ Stephen Blake has highlighted the role of the Mughal imperial birthday celebration as a "secular, dynastic [rite] of political legitimacy." ${ }^{, 83}$ Started under Akbar, the imperial birthday deliberately integrated Islamic and Indic traditions, and was held twice each year, on Akbar's lunar birthday, according to the Islamic Hijri calendar, as well as on his solar birthday, according to the Ilahi calendar. ${ }^{84}$ The emperor would be weighed on a ceremonial scale, one pan for his body and the other for various goods, including foodstuffs and farm animals, as well as luxury items such as fine cloth, precious metals, or perfumes, which would be given in charity and as gifts to loyal retainers. After the weighing, honours, horses, promotions, and raises would be distributed to key administrators and officeholders, who would also be expected to present the emperor with gifts of jewels, silver, and gold to enact their part of the ritual relationship. Blake notes that the wide range of items given in charity indicates that the ceremony was not intended simply as a display for the more elite imperial administrators, but incorporated the entire socioeconomic spectrum of the empire. ${ }^{85}$ Bhatt's closing remark on the fact that "none except the Government servants" knew the date of the queen's birthday was intended as an indictment of the distance between European and Indian subjects of the British empire. This distance itself became a topic of commentary in Indian periodicals: Native Opinion, a part-English, part-Marathi biweekly paper from Bombay ${ }^{86}$ published an article in English titled "Lack of Sympathy between Ruler and Ruled" in $1873 .{ }^{87}$

Newspapers also drew attention to the emptiness of British rituals of imperial sovereignty, which focused on superficial elements such as titles or ceremony, but failed to foster, or even to comprehend, the deep affective ties which should have bound ruler and ruled. Nearly simultaneous with the Vernacular Press Act of 1878, the Government of India announced, following the imperial assemblage at Delhi, that Queen Victoria had assumed the title of Empress of India. The editor of the Nur-ul-Absar, after publishing an Urdu translation of the correspondence of the Secretary of State for India on the assumption of title, commented:

It is the belief of the ministers of Her Majesty that the assumption of the title of Empress of India will stimulate the loyalty and attachment of the native population towards the English Government. No doubt the proclamation of the Imperial title produced as much effect on the minds of the people as a mere proclamation could, i.e., it excited pleasure or gladness for the moment. In order that its influence may be permanent, the 
Government officers who are deputed to India by Her Majesty to conduct the administration of the country, should treat the natives in the same way as a king would treat the people of his own race. The names of Shere Shah, Salim Shah, and Akbar are still remembered by the people. It is our earnest prayer to Heaven that our present rulers may be able to act in the same way so that the name of the English Government may also be long remembered in future. This is only possible in case the people enjoy prosperity, peace, and comfort. ${ }^{88}$

Writers such as Bhatt referenced popular memory and perception, things that "everyone knows" or "everyone agrees upon," as a means of understanding the lasting impact of particular sovereigns, concepts, or practices. Reference to a collective understanding of morality highlighted the affective bonds which should, ideally, exist between subject and ruler, and the substance which underlay the rituals and policies which had connected them.

Even ostensibly "loyalist" texts and acts took place within a Mughal political cosmology. Milinda Banerjee has described this as a "vernacularisation" of monarchy, through which the person of the sovereign could become a space in which Indians across social classes might "voice their personal or national hopes and ambitions." "89 Bhartendu Harischandra, in addition to his own poems in praise of British monarchs, published a long and fulsome article by Pandit Badri Dat in praise of Queen Victoria on her birthday on 27 May $1878 . .^{90}$ The writing of this particular genre of essay, a qasida, or work of praise for the sovereign, alongside Harischandra's attempt to present flowers to Prince Alfred during his visit to Banaras, were both acts which brought the British monarchy into a Mughal cosmology, demanding reciprocity from the ruler. ${ }^{91}$ Mughal sovereignty was broadly understood as legitimated by its accessibility to a broader public, via means both formal (petitions, formal delegations, public rituals) and informal (approaches to the emperor in public audience or during a public appearance). Harischandra was prevented from offering his gift by the lieutenant-governor of the North-Western Provinces, William Muir, and instead held a private literary gathering in his house, ${ }^{92}$ turning what should have been a "public" affirmation of the bond between ruler and subject into a household gathering, rendered "public" only by newspaper notices of its occurrence, and by the subsequent publication of the poems.

This physical distancing of subjects from the sovereign, with exceptions only for the carefully policed and choreographed darbars, came to symbolise, for Indian writers, the civilisational and racialised differences inherent to British practices of imperial sovereignty. Darbar was a Mughal term for a court, referring both to the imperial court and to those held by local governors and princes. The term was recycled by colonial governors but came to signify a one-sided display of pageantry; a public reception rather than a true 'court' responsive to its subjects. Balkrishna Bhatt's Hindi Pradip explicitly referenced "the dishonour of dark skin" in an essay against the treatment of an Indian tahsildar (revenue collector) by the district superintendent of police, published in August of 1878: "We may become as learned and wise as the four-faced Brahma, but still we cannot get rid of the stain of being dark coloured which is permanently fixed on our forehead. We therefore deserve punishment for this sin, so much so that we should be treated not even as human beings but as brutes." 93 
During the 1870 s, the discourse of Mughal sovereignty signified by the AkbarAurangzeb comparisons was increasingly used to explain the danger that institutional racism posed to the British imperial project. Indian editors drew on Ottoman and wider global Islamic conversations, often conveyed via newspaper reprints as well as through personal correspondence and connections, to argue that racism was the major distinction between older forms of patrimonial bureaucratic Islamic empire and contemporary European colonial regimes. Cemil Aydin's work however provides an important qualifier: Muslim (and South Asian) writers were protesting imperial racism, rather than "empire itself." 94 The Akbar-Aurangzeb discourse was part of a broader conversation about fairness and justice within an imperial context, rather than, as Lytton's government would read it, active sedition. Global Muslim networks helped to transmit news of the behaviour of the Ottoman Empire, among the last sovereign Muslim world powers, to an Indian public increasingly aware that they were able to organise and act together across distance.

The theme of an imperial rule of difference as a denial of Indian humanity was repeated across newspapers throughout the debates of the later 1870s. The Awadh Akbar ran an editorial in June of 1878 asking why Europeans regarded only Christians as deserving of consideration as "human beings." 95 Noting that Europe was praised for its "civilisation" and "education," and the "general belief" that "Europeans love justice and are a kind hearted people," the editorial remarked that "if the effect of that education and civilisation is that the man who has received that education and civilisation looks upon all persons, except those belonging to his own race and professing the same creed with him, as being inferior to mankind, we bid adieu to that education and civilisation." Justice, the article insisted, was not the sole right of a particular group, and the denial of the humanity of "other tribes" living in Turkey rendered them "a kind of immoveable property, so that any king who is strong may take possession of them without the least hesitation." In the same issue of the Awadh Akbar, in another article on a proposal in an English-language paper to "disarm" princely states, which was seen as a transgression of their sovereignty by most of the Indian papers, the editor cautioned the government to "adopt the policy of Akbar and not of Aurangzeb."96

The Sadharani remarked in a similar vein:

It is a matter of regret that the British nation has not yet been able to understand the meaning of the word "Sovereign." In their eagerness to rule, to legislate, to amass wealth and equally to spend it, they have not paid any particular attention to the cardinal duty of a sovereign - namely, conciliating the subjects. The authorities should always remember the famous words of the Court of Directors- "It will not do merely to do justice, but the people should be convinced that justice has been done. ${ }^{, 97}$

Although the Sadharani was quoting a colonial source, they chose a passage consonant with the thrust of the akhlaq texts. Chief among the virtues for which Akbar was celebrated was the inclusion of a diverse array of Indians at all levels of the imperial administrative and military order, creating a "representative" ethic of imperial governance. "Raja Bir Bal was the prime minister of Akbar," wrote Bhatt, who noted further that Akbar "looked upon his subjects as his children. But now the times have quite 
changed. To say nothing of offices like those held by Bir Bal and Todar Mal under the Mughal emperors, no native is now admitted to the higher ranks of the public service." 98 Bhatt argued that barring Indian subjects from positions of responsibility was a sign of a lack of trust in both their ability and their loyalty. The ethic that underpinned Akbar's reign, and the Mughal empire at its height, Indian editors concurred, was the extent to which all of the empire's peoples were represented, even at high levels, in the government. The Benares Akhbar had reported in April of 1875 that some English news-writers had expressed jealousy of the "independence" of their Indian counterparts. The editor responded:

The Editor assures Government that as long as Government treats its European and its Hindustani subjects equally, without any distinction of colour or creed, so long will its sovereignty in India be more powerful and firm than that of Akbar was; but that the moment it begins showing partiality to men of its own nation, it must rest assured that the days of Aurangzeb have come, and that the end of the empire is near. ${ }^{99}$

The Vrita Dhara, a Marathi-language paper, published a series of articles on the nature of kingship on 6 and 8 April, 1878. In the 8 April essay, the writer noted that all subjects of Queen Victoria did not "enjoy equal rights and privileges," because "they [Englishmen] have a national government. They are, as it were, the children of a wife, whereas we are . . the children of a mistress." ${ }^{100}$ Referencing the Magna Carta as a constraint on the power of English kings and a guardian of the rights of English people, the author argued that "no such charter has ever been granted to us by any king of England. . . Many of our countrymen say that in the Royal Proclamation of 1858, and on several public occasions, the Government has promised that it will recognise no distinction of creed, colour, or race, and look upon its English and native subjects with an eye of equality." But, the editors of the Vrita Dhara concluded, "as the Government does not act up to its declarations," they "accuse it of falsehood or dishonesty." 101 The word used in Marathi was luchchagiri, one demonstrating low or base behaviour, signifying action that is corrupt, shameless, or depraved: far removed from the correct princely behaviour modelled in akhlaq texts. The author noted, with apparent sarcasm, that "no man acts up to his words," and that relations between Indians and Englishmen were marked with "hypocrisy" on both sides, emphasising the mistrust and mutual suspicion between ruler and ruled.

These essays demonstrate the persistence of, and influence of, strands of Indian liberal thought, in the "downward hermeneutic" identified by Bayly, ${ }^{102}$ but also in the resilience of traditions of Mughal political thought which saw compassion and connection between sovereign and subject as markers of civilisation and just rule, and theorised imperial authority as predicated on its ability to mediate diverse interests across the empire. The invocation of Aurangzeb as a warning of the fate that befell "tyrants" brought British governance under the lens of comparative and historical political thought on empire. But rather than conform to discourses of imperialism directed by colonial authorities, Indian newspapers both reinterpreted Mughal sovereignty and appropriated official texts such as Queen Victoria's Proclamation of 1858 for themselves as a charter of rights, deliberately placing it within the political and ethical cosmology of akhlaq. ${ }^{103}$ 


\section{Circulation, Authority, and Networked Authorship}

Karin Barber writes that "the addressivity of texts - their ways of 'turning to' an audience - not only reveals cultural assumptions about how people exist together in society, but also plays a part in constituting audiences as particular kinds of collectivity."104 Barber, referring to Mikhail Bakhtin's theory of speech-acts, emphasises how "utterances" themselves, in whatever format, initiate processes that collect, collate, and disrupt. To understand how each of these invocations of Akbar and Aurangzeb worked as speech-acts, we must understand how they circulated across social registers, genres, and material spaces in their transmission, taking on additional meaning through each iteration. It was not just the content, but the form and mechanism of communication which shaped new ideas about empire.

We have already discussed how collective reading practices meant that even publications with small print runs could engage audiences of many hundreds more. Many of the in-depth studies of Indian publishers have focused on larger presses, whose proprietorpublishers produced newspapers as well as books and pamphlets. ${ }^{105}$ The literate, and listening, public was however swiftly expanding throughout the nineteenth century: before 1857, subscribers to the Delhi Urdu Akhbar paid the sum of two rupees per month, or twenty rupees annually, for the paper, in an era when five rupees was considered a princely stipend. ${ }^{106}$ By the mid-nineteenth century, the falling costs of printing and the spread of literacy and group reading meant that publishers imagined a much broader audience, and a very different kind of public. There were numerous periodicals published on a much smaller scale, with their editors buying, begging, and borrowing time from typesetters and lithographers at larger presses, continually emerging and failing across the course of the colonial period. ${ }^{107}$ Deeptanil Ray and Abhijit Gupta have stressed that the ephemerality of newspapers and periodicals has left us with an incomplete archive, particularly for newspapers published in manuscript form or in brief print runs, ${ }^{108}$ leaving us with suggestive fragments, often mediated through colonial state archives and colonial censorship. Many, if not most, of the newspapers of the period are no longer extant, and colonial press surveillance records, crucial as they are in providing a window into a broader swathe of Indian-language periodicals, tended to record only specific topics, skewing our understanding of the broader world of Indian print. ${ }^{109}$ The Indian newspaper reports, beginning in 1868 and preserved in the Record Department Papers of the Oriental and India Office Collections, (now the Asia and Pacific Department) of the British Library, consisted of translations and synopses of articles appearing in the Indian-language press across the different provinces of British India. Reports were submitted weekly, and consolidated into the Selections from the Vernacular Newspapers series, which was published internally by Government in an (increasingly futile) effort to monitor the hundreds of local newspapers which sprang up across India during the $1860 \mathrm{~s}$.

We must see colonial Indian print as embedded in, rather than superseding, preexisting forms of social and cultural communication, while theorising audience as an integral part of the print sphere. Newspapers deployed several novel genres and reworked 
older forms during the 1860 s and 1870 s, which suggests that they developed in continual conversation with their readers and listeners. In commentary discussing statecraft and empire, four newspaper forms in particular repay attention: reprints, serialised fiction, dialogues, and "dreams." The latter refers to speculative pieces which used the device of a dream to observe contemporary events from a new perspective. Dreams were also connected to prophecy, and thus could act as intercessors between mortal and cosmological forces. ${ }^{110}$ All four relied on older conceptions of authorship and audience expectation, but utilised the new periodicity and wider circulation of print to innovate and entertain.

The widespread practice of reprinting articles from other newspapers represented both an innovation and a continuation of modes of oral and manuscript cultural transmission: a continuation in that older notions of authority were preserved, ${ }^{111}$ but an innovation in that the periodicity and the density of these interpenetrating networks of commentary represented something new for readers and listeners. Writing on the newspaper cultures of the United States in the mid-nineteenth century, Ryan Cordell has argued that "circulation often substituted for authorship; the authority of the newspaper rested on networks of information exchange that underlay its production... [and] the newspaper's primary value stem[med] from whom and how it connected."112 Cordell suggests that seeing nineteenth-century authorship as networked allows us to expand our focus on individual authorship and "ownership" of ideas to instead "see composition in terms of writers, editors, compositors, and readers enmeshed in reciprocal, mutually dynamic relationships of reception, interpretation, and remediation." 113

This model of networked authorship, which sees print entrepreneurs not as "creating" but as addressing ongoing conversations, allows us to understand nineteenth-century newspapers as sites of interaction rather than as sources of discourse. Like American newspapers of the same era, Indian newspapers were filled with anonymous or pseudonymous texts, often written by the editors themselves or demanded from their friends, along with reprints from other papers. The reprinting process was transparent, with source newspapers clearly named in most cases. That so many papers devoted space to reprints, given the financial constraints under which they operated, suggests that reprints were themselves valuable, and that the imperial, transregional, and global connections that the reprints represented for readers and editors alike were worth the cost. Lithographic printing or typesetting was a major investment for some papers, which were largely, in this period, reliant on subscriptions, and, less often, patronage from landed or princely benefactors for their continued existence. ${ }^{114}$ The value of reprinted articles and editorials on shared topics within a system characterised by textual and oral exchanges and borrowing meant that circulation itself, as well as the charisma of the individual creator, could bring value.

Networked authorship allowed newspapers to connect disparate audiences and editors across India to those around the world. Indian and Ottoman newspaper editors regularly exchanged subscriptions, and much "international" news, particularly in North India, was gleaned from Ottoman as well as British and other European sources. ${ }^{115}$ Hindustani newspapers in Madras were often almost entirely composed of material reprinted from 
Urdu papers in northern India, and were often therefore dismissed by colonial officials as, alternatively, innocuous or insignificant. ${ }^{116}$ We have evidence that readers of the Madras newspapers, however, took action based on reprinted news items about the Turko-Russian conflict. Indians in general had donated generously to humanitarian relief efforts in the Ottoman Empire, ${ }^{117}$ and the Committee of the Red Crescent felt that Urdu audiences in Madras were important enough to merit sending subscription cards via local newspapers to solicit donations. The editor of the Shams-ul-Akhbar of Madras wrote an open letter to his readers in March of 1878: "We have received from Constantinople three hundred illuminated cards, sent by the Committee of the Red Crescent inviting subscriptions to that valuable Institution. We have circulated these cards to our subscribers, but as there were not enough to go around, we publish a facsimile of the card in this number." 118 These cards, following a tradition that had connected a Persianate "cosmopolis" of letters during the seventeenth and eighteenth centuries, sent to individual editors and their subscribers, provide a powerful image of the tangible global as well as regional connections being forged between different audiences through newspaper reprints. ${ }^{119}$

Russian expansion and aggression towards the Ottoman Empire prompted a rising demand for global news among Indian newspaper audiences during the 1870s. In northern India, rumination on the nature of empire, geopolitics, and just governance in the context of the Russo-Turkish conflict was delivered to readers in multiple formats, including serialised fiction. The Awadh Akhbar, among northern India's first daily newspapers and one which repeatedly enjoined the Government of India to "adopt the policy of Akbar and not of Aurangzeb," 120 instituted a new regular feature: Sarhad/maidan-e jang ki tazatarin khabren (latest news from the frontier/battlefield) with accompanying illustrations and maps to orient their readers. The Awadh Akhbar had always relied on the popularity of fiction and poetry to entice subscribers, and its episodic stories were often in direct conversation with contemporary events, creating an immersive experience for its audience. ${ }^{121}$ The popular Urdu "novel" Fasana-e Azad represented deep experimentation with the form. Written by Pandit Ratan Nath Sarshar, editor of the Awadh Akhbar, it followed the fictional Azad as he courageously fought alongside Turkish soldiers against the Russians. ${ }^{122}$ Those reading (or listening) could both absorb the daily battlefield accounts and then, through Azad's adventures, experience those events vicariously for themselves. Passionate readers' letters to the Awadh Akbar provide evidence for a community of readers who both hotly anticipated new instalments of Azad's adventures and felt free to offer criticism and advice to the author and editor of the paper, which ranged from requests for more careful line-editing to requests about content. ${ }^{123}$

The concept of networked authorship also allows us to understand how oral culture could be in close conversation with print. Dialogues, which allowed writers to frame their commentary according to oral traditions of debate, popular drama, and entertainment, were a common and popular format for political commentary and satire in mid-nineteenth-century Indian newspapers. Newspaper dialogues could also replicate the novel formats of the colonial courtroom, the crowded town hall meeting, or, indeed, the censor's office. When the colonial state began to police print communication, Indian 
newspapers drew upon Mughlai forms as well as liberal thought to argue not just for their continued existence, but for print as a "public good."

On 17 March 1878, the Sadharani published "Dream." 124 The author, "dwelling upon the fall of the Mahomedans, the rise of the English, the fall of Turkey, the rise of Russia, the oppression of the ruling power, the revolt of the subjects, laws and bye-laws, taxes," encountered a Pandit sighing over the 1878 Press Act, which had "undone" forty-two years of comparative press freedom. Troubled, the writer fell asleep, and found himself in Calcutta, watching people stream into the crowded Town Hall from all directions, and he asked what was going on. "The misfortune of the native papers," was the reply, "a monument to Lord Lytton; we have come to show our proof-sheets to the censor." From this point, the writer steps back and the "dream" unfolds as a dialogue between the President, head of a commission of British censorship officials, and an editor, who, "an article in his right hand and a newspaper in his left . . . stood trembling." The President, upon hearing the first line of the article in question, on "the liberty of the Newspaper Press," interrupts with, "That will do. This is very bad. The liberty of the newspapers has been taken away; why do you write about it again? Read another." When the editor begins with a new article, on the topic of Mr. Eden as a "friend to the Bengalis," the President again interjects to say that calling a European a "friend" of Indians amounts to "Abuse of Europeans and sedition." Upon hearing that the news includes a story about an indigo-planter who beat his servant to death, the President exclaims, "Well, if there has been a death, the Magistrate will try the case, the newspapers must not criticise it. Did you ever hear of a European commit a murder?" When the editor protests that there will be no content for his paper, and that his subscribers will be very unhappy, he is dismissed summarily.

The "dream," which could be used as a vehicle for a "story within a story" in serialised fiction or in long qissa or dastan romances and epics, was used by the Sadharani as a means of creating an ungovernable space from which to comment on state surveillance and censorship. Prefacing a "story of a father and his children," a deliberately thinly veiled parable of rule, the Howrah Hitkari wondered if "henceforth stories and legends [were] all that native newspapers can contain with safety." 125 Papers often combined reports of prophecies or "magical" occurrences alongside articles on science, discourses on religion or law, and of course poetry and fiction. ${ }^{126}$

Dialogue was a format used most extensively by the Indian Punches, ${ }^{127}$ satirical magazines, and was used to underscore divergences from expected or appropriate behaviour in both daily life and concerning affairs of state. Yet as the above shows, dialogue could also be a vehicle for serious news items, which traded both on the dark humour of the Punch vignettes and on the generic conventions of popular theatre, bringing otherwise dry editorial commentary to life for listeners. At the same time conversations about the significance of titles and honours were being discussed in editorials, the Akhbar-i-Tamanni published an Urdu poem in the form of a dialogue between "Englishmen" and Indian interlocutors. ${ }^{128}$ The Indians argue that without genuine responsibility, salaries, and integration into the imperial system, titles are empty and infantilising. The Englishmen proceed to completely misunderstand the substance of 
their complaints, greeting each criticism as enthusiastically as if it were praise for colonial policy, not bothering to disguise venal motives for government action. The dialogue demonstrated the Urdu élan with language, which was itself a form of entertainment, for example in its puns: "You had the honour of sitting on chairs [kursiya] at the darbar [Imperial Assemblage held at Delhi, 1877], and, therefore, we must now make kursi (fools) of you" [Kursi was the name of a pargana in Awadh whose historical inhabitants were "proverbial for their folly"]. ${ }^{129}$ But it also tackled serious issues, asking why the English could feel no compassion for their starving subjects. By mixing genres as well as tone and linguistic register, the newspapers could appeal to multiple audiences and enter into multiple conversations and debates simultaneously.

\section{Censors and Surveillance as a Part of the Print Sphere}

Newspaper authors and audiences could ascribe meaning to state authority which, by addressing power, drew mechanisms of control into a conversation of their own making. This is particularly evident in how newspapers used government surveillance to forge new channels of communication between ruler and ruled. The internal government monitoring of the vernacular press in India, as Neeladri Bhattacharya has suggested, provided a source for government officials to see themselves "through the eyes of the public," and to understand, respond to, and, crucially, "define the limits of public debate." 130 Indian publishers were also, however, acutely aware of surveillance and censorship from the 1860 s and 1870 s, and "those being watched used the public eye to speak back to the masters, and provided misinformation to those who sought to know." ${ }^{\text {"131 }}$ Beyond the deliberate sowing of misinformation, however, surveillance opened a direct channel of communication between the colonial state and its counterpublics.

Indian editors directly addressed the Government Reporters, government-employed translators who monitored the press and submitted translations and reports. Including Reporters as a part of their readership both brought censorship to the awareness of a wider public audience, and made the censors a formal part of the authorship network of the periodicals. Reporters were issued instructions about translations, and, after the Vernacular Press Act and the infamous 150 newspaper extracts which were used to support it, ${ }^{132}$ their translation skills were regularly questioned. The editor of the Sahachar, a paper whose near demise after the Press Act of 1878 inspired sympathy in editors across India, wrote that translations from the newspapers published in Bengal were performed by "a foreigner and the articles are not fully translated, we ask Government to furnish Native Editors with the Weekly Reports and other official communications."133

Communication via government surveillance extended beyond such communications. An Odisha paper, the Utkal Dipika, primarily a literary and educational journal founded in 1866, prominently featured a lively Letters to the Editor column which brought everyday hardships to the attention of colonial officials, and also sponsored memorandums to redress popular grievances. ${ }^{134}$ Indian editors also used their platform to offer advice to officials. There was widespread public concern, from the 1870s on, that Russian aggression against the Amir of Kabul would lead to a second Russo-Afghan war, which would 
indeed prove to be the case. One editor warned that the "English government should look well after the movements of the Russians, who are rapidly approaching Afghanistan, and not put much faith in their promises."

\section{Conclusion: The "Language of Opinion"}

We feel sure that our grand-children and great-grand-children, while reading that portion of the History of India which refers to this measure of the 14th March 1878, will die with laughter. The Act, for which we now weep, will furnish them with an occasion for amusement; and they will be ready to exclaim "What a pity! Was every member of Lord Lytton's Council mad, that such mighty preparations were made for killing a number of petty scribblers." 136

Partha Chatterjee argued that, following draconian censorship in the early and midnineteenth century, "the idea of a free press would exist in India only to the extent that the language of opinion was English. Everything else was subject to the rule of colonial difference and liable to be declared as exceptions to the universal principle of liberty." 137 Yet, while there were certainly differences in the degrees of freedom afforded the Indian and English-language presses (differences which were well understood by Indian as well as British editors), the evidence from Indian newspapers suggests that the press of the mid- to late nineteenth century did constitute a critical public able to, as Bhattacharya put it, co-opt, augment, subvert, and transform the "languages of reason" which were being used to silence them. Jennifer Dubrow's evocative argument that South Asian print publics and imaginations were not "forever colonised" as "perpetual consumers of modernity," to use Partha Chatterjee's phrasing, but were able to "dream anew" using print, better fits with the imaginative repackaging, and reinvention, of old and new texts, traditions, and stories in the periodical press. ${ }^{138}$

Rather than see print-capitalism primarily as a tool of colonial elite interests, then, we might instead think more about what French cultural historian Roger Chartier proposed, in The Order of Books, as the reader's liberty. Taking a phrase from Michel de Certeau, Chartier suggests that readers (and editors) might be "poachers."139 "The book always aims at installing an order," but books require readers to "give them meaning." 140 De Certeau argued that it was this "dialectic between imposition and appropriation" which galvanised the creation of new print publics, a point that we might apply to the technologies and materiality of print in South Asia. ${ }^{141}$ Chartier and Gonzalez suggest the historian's job is to "reconstruct the variations that differentiate the 'readable space' (the texts in their material and discursive forms) and those which govern the circumstances of their 'actualization' (the readings seen as concrete practices and interpretive procedures)."142

Discourses of just rule in the popular press highlight a tension inherent in both conceptions of the sovereign and of the public. As David Gilmartin has argued, the public "embodied 'the conundrum of the king's authority' in new form, defining both a space of worldly conflict and debate and - at the very same time - an image of unity implicit in the idea of a 'public' voice." 143 The akhlaqi tradition, and references to Akbar and Aurangzeb, could be combined with ideas about a free press to construct a new counter- 
discourse, instrumentalising a broad familiarity with core texts and concepts across both Indian publics and British officialdom, and to argue for a truly "all-India" sociopolitical mission. We can also see the lineaments of later divisions: a press tradition more critical of the Mughal legacy in Bengal, for example, ${ }^{144}$ and, in Hindi Pradip itself, the beginnings of a Hindi public sphere which would gradually push the vibrant Persianate cosmopolis to the margins by the twentieth century.

The press became not simply an interface with the colonial state, but a forum for debate about the nature of Indian society in a shifting multilingual and global context. In the $1870 \mathrm{~s}$, what is most striking about the Indian press is its interdependence and multiple connectivities: presses connected writers, listeners, and readers, calligraphers, storytellers, reporters, and gossips, cartoonists and government translators, Indian princes and indeed the Viceroy himself, all "authors" and "authorities" of Indian news. The crises of the 1870 s produced an experimental "civic drama" through which the print sphere tested conceptions of sovereignty, a drama which would define Indian print spheres, publics, and political thought for decades afterwards.

\section{Acknowledgements}

I am very grateful to Emma Hunter, Leslie James, and the other participants in our series of 'colonial print' conversations over the years. While any errors are of course my own, I have benefitted enormously from their insights, questions, and discussions.

\section{Bibliography}

\section{Unpublished Primary Sources}

India Office Records, British Library: Selections from the Vernacular Newspapers Published in the Panjab, North-Western Provinces, Oudh, Central Provinces and Berar. 4 vols. Allahabad: N.-W.P. and Oudh Government Press, 1878-1881. [SVN]

\section{Published Primary Sources}

Birdwood, George. "The Native Press of India." Journal of the Society for Arts 25:1270 (1877), 399-428.

Fakhr-i-Mudabbir. Ta'rikh-i Fakhr al-Din Mubarak Shah (Introduction to the Shajara-Yi-Ansab), ed. Edward Denison Ross. London: Royal Asiatic Society, 1927.

Frere, Bartle. "The Means of Ascertaining Public Opinion in India." Journal of the East India Association 5:4 (n.d.), 102-72.

Sharar, 'Abdulhalīm. Lucknow, the Last Phase of an Oriental Culture. UNESCO Collection of Representative Works. London: Elek, 1975.

\section{Newspapers \\ Hindi Pradip \\ Native Opinion \\ Times of India}




\section{Secondary Sources}

Alam, Muzaffar. The Languages of Political Islam: India, 1200-1800. London: Hurst, 2004.

Alavi, Seema. Muslim Cosmopolitanism in the Age of Empire. Cambridge, Mass.: Harvard University Press, 2015.

Aydin, Cemil. The Idea of the Muslim World: A Global Intellectual History. Cambridge, Mass.: Harvard University Press, 2017.

Banerjee, Milinda. The Mortal God: Imagining the Sovereign in Colonial India. Cambridge: Cambridge University Press, 2017.

Banerjee, Sukanya. Becoming Imperial Citizens: Indians in the Late-Victorian Empire. Durham, N.C.: Duke University Press, 2010.

Barber, Karin. The Anthropology of Texts, Persons and Publics: Oral and Written Cultures in Africa and Beyond. Cambridge: Cambridge University Press, 2007.

Barns, Margarita. The Indian Press: A History of the Growth of Public Opinion in India. London: Allen \& Unwin, 1940.

Bayly, C. A. Empire and Information: Intelligence Gathering and Social Communication in India, c. 1780-1870. Cambridge: Cambridge University Press, 1996.

"Patrons and Politics in Northern India." In Locality, Province and Nation: Essays on Indian Politics 1870 to 1940, 29-68. Cambridge: Cambridge University Press, 1973.

- Recovering Liberties: Indian Thought in the Age of Liberalism and Empire. Cambridge: Cambridge University Press, 2012.

Bayly, C. A. "Religion, Liberalism and Empires: British Historians and Their Indian Critics in the Nineteenth Century." In Tributary Empires in Global History, ed. Peter Fibiger Bang and C. A. Bayly, 21-47. Basingstoke: Palgrave Macmillan, 2011.

Bhatnagar, Ram Ratan. The Rise and Growth of Hindi Journalism, 1826-1945: Being an Attempt at a History of Hindi Journalism in Historical, Chronological and Evolutionary Perspective, on the Basis of Research Work Done during the Years 1941-46 under the Supervision of D. P. Shukla of Hindi Department of the Allahabad University. Allahabad, Abhyudaya Press: Kitab Mahal, 1947.

Bhattacharya, Neeladri. "Notes Towards a Conception of the Colonial Public." In Civil Society, Public Sphere, and Citizenship: Dialogues and Perceptions, ed. Rajeev Bhargava and Helmut Reifeld, p-56. New Delhi: Sage Publications, 2005.

Blake, Stephen P. "Returning the Household to the Patrimonial Bureaucratic Empire: Gender, Succession and Ritual in the Mughal, Safavid and Ottoman Empires." In Tributary Empires in Global History, ed. Peter Fibiger Bang and C. A. Bayly, 214-26. Basingstoke: Palgrave Macmillan, 2011.

Bonea, Amelia. The News of Empire: Telegraphy, Journalism, and the Politics of Reporting in Colonial India c. 1830-1900. Oxford: Oxford University Press, 2016.

Certeau, Michel de. "Reading as Poaching." In The Practice of Everyday Life, trans. Steven Rendall, 165-76. Berkeley: University of California Press, 2002.

Chandra, Sudhir. The Oppressive Present: Literature and Social Consciousness in Colonial India. Delhi: Oxford University Press, 1999.

Chartier, Roger. The Order of Books: Readers, Authors, and Libraries in Europe Between the Fourteenth and Eighteenth Centuries. Stanford: Stanford University Press, 1994.

— (1992), 49.

Chatterjee, Partha. The Black Hole of Empire: History of a Global Practice of Power. Princeton, N.J: Princeton University Press, 2012.

- The Nation and Its Fragments: Colonial and Postcolonial Histories. Princeton Studies in Culture/Power/History. Princeton, N.J.: Princeton University Press, 1993.

Cohn, Bernard S. Colonialism and Its Forms of Knowledge: The British in India. Princeton, N.J.: Princeton University Press, 1996. 
Conrad, Sebastian. "Enlightenment in Global History: A Historiographical Critique." The American Historical Review 117:4 (1 October 2012), 999-1027.

Cordell, Ryan. "Reprinting, Circulation, and the Network Author in Antebellum Newspapers." American Literary History 27:3 (September 2015), 417-45.

Dalmia, Vasudha. "Merchant Tales and the Emergence of the Novel in Hindi." Economic and Political Weekly 43:34 (2008), 43, 45-7, 49-60.

- The Nationalization of Hindu Traditions: Bharatendu Harischandra and Nineteenth-Century Banaras. Oxford: Oxford University Press, 1997.

Das Gupta, Uma. Rise of an Indian Public: Impact of Official Policy, 1870-1880. Calcutta: Rddhi, 1977.

Dubrow, Jennifer. Cosmopolitan Dreams: The Making of Modern Urdu Literary Culture in Colonial South Asia. Honolulu: University of Hawaii Press, 2018.

Fraser, Nancy. "Rethinking the Public Sphere: A Contribution to the Critique of Actually Existing Democracy." Social Text 25/26 (1990).

Freitag, Sandria B. Collective Action and Community: Public Arenas and the Emergence of Communalism in North India. Berkeley: University of California Press, 1989.

Freitag, Sandria B. "Postscript: Exploring Aspects of 'the Public' from 1991 to 2014." South Asia: Journal of South Asian Studies 38:3 (3 July 2015), 512-23.

Gelvin, James L., and Nile Green. Global Muslims in the Age of Steam and Print. Berkeley: University of California Press, 2013.

Ghosh, Anindita. "The Many Worlds of the Vernacular Book: Performance, Literacy and Print in Colonial Bengal." In Books without Borders, Volume 2: Perspectives from South Asia, ed. Robert Fraser and Mary Hammond, 34-57. Basingstoke: Palgrave Macmillan, 2008.

_ . "An Uncertain 'Coming of the Book': Early Print Cultures in Colonial India." Book History 6:1 (2003), 23-55.

Gilmartin, David. "Imperial Sovereignty in Mughal and British Forms." History and Theory 56:1 (March 2017), 80-8.

- "Rethinking the Public through the Lens of Sovereignty." South Asia: Journal of South Asian Studies 38:3 (3 July 2015), 371-86.

Green, Nile. "Persian Print and the Stanhope Revolution: Industrialization, Evangelicalism, and the Birth of Printing in Early Qajar Iran." Comparative Studies of South Asia, Africa and the Middle East 30:3 (2010): 473-90.

Guha, Ramachandra, ed. Makers of Modern India. Cambridge, Mass: Harvard University Press, 2011.

Gupta, Charu. Sexuality, Obscenity, Community: Women, Muslims, and the Hindu Public in Colonial India. Delhi: Permanent Black, 2001.

Habermas, Jürgen, and Thomas Burger. The Structural Transformation of the Public Sphere: An Inquiry into a Category of Bourgeois Society. Cambridge: Polity Press, 2008.

Handa, Rajendra Lal. History of Hindi Language and Literature. Bombay: Bharatiya Vidya Bhavan, 1978.

Hasan, Farhat. "Forms of Civility and Publicness in Pre-British India." In Civil Society, Public Sphere and Citizenship: Dialogues and Perceptions, ed. Rajeev Bhargava and Helmut Reifeld, 84-106. New Delhi: Sage Publications, 2005.

Haynes, Douglas E. Rhetoric and Ritual in Colonial India: The Shaping of a Public Culture in Surat City, 1852-1928. Berkeley: University of California Press, 1991.

Hossain, Rokeya Sakhawat. Motichur: Sultana's Dream and Other Writings of Rokeya Sakhawat Hossain, ed. Ratri Ray and Prantosh Bandyopadhyay. First ed. New Delhi: Oxford University Press, 2015.

Ingram, Brannon, J. Barton Scott, and SherAli K. Tareen, eds. "What Is a Public? Notes from South Asia." South Asia: Journal of South Asian Studies 38:3 (2015), 357-70. 
Kamra, Sukeshi. The Indian Periodical Press and the Production of Nationalist Rhetoric. New York: Palgrave Macmillan, 2011.

Khanduri, Ritu Gairola. Caricaturing Culture in India: Cartoons and History in the Modern World. New York: Cambridge University Press, 2014.

Kundu, Manujendra. "The Dramatic Performances Act of 1876: Reactions of the Bengali Establishment to Its Introduction." History and Sociology of South Asia 7:1 (January 2013), 79-93.

Lal, Vinay. "Aurangzeb, Akbar, and the Communalization of History." MANAS (blog), UCLA Social Sciences, http://southasia.ucla.edu/history-politics/mughals-and-medieval/aurangzeb/ communalization-of-history/.

Majeed, Javed. "Narratives of Progress and Idioms of Community: Two Urdu Periodicals of the 1870s." In Negotiating India in the Nineteenth-Century Media, ed. David Finkelstein and Douglas M. Peers, 135-57. Basingstoke: St. Martin's Press, 2000.

Metcalf, Barbara Daly, ed. Moral Conduct and Authority: The Place of Adab in South Asian Islam. Berkeley: University of California Press, 1984.

Mir, Farina. The Social Space of Language: Vernacular Culture in British Colonial Punjab. Berkeley: University of California Press, 2010.

Mohanty, Sachidananda. Periodical Press and Colonial Modernity: Odisha, 1866-1936. First ed. New Delhi: Oxford University Press, 2016.

Moin, A. Azfar. The Millennial Sovereign: Sacred Kingship and Sainthood in Islam. New York: Columbia University Press, 2010.

Moitra, Swati. "Reading Together: 'Communitarian Reading' and Women Readers in Colonial Bengal." Hypatia 32:3 (2017), 627-43.

Mookerjee, Firoze. Lucknow and the World of Sarshar. Karachi: Saad Publications, 1992.

Naregal, Veena. Language, Politics, Elites and the Public Sphere: Western India under Colonialism. Anthem South Asian Studies. London: Anthem, 2002.

Natarajan, J. History of Indian Journalism. New Delhi: Publications Division, Ministry of Information and Broadcasting, Government of India, 1955.

Orsini, Francesca. The Hindi Public Sphere, 1920-1940: Language and Literature in the Age of Nationalism. Oxford: Oxford University Press, 2002.

_. Print and Pleasure: Popular Literature and Entertaining Fictions in Colonial North India. Ranikhet: Permanent Black, 2009.

_ . "What Did They Mean by 'Public'? Language, Literature and the Politics of Nationalism." Economic and Political Weekly 34:7 (13 February 1999): 409-16.

O'Sullivan, Michael. "Pan-Islamic Bonds and Interest: Ottoman Bonds, Red Crescent Remittances and the Limits of Indian Muslim Capital, 1877-1924." Indian Economic \& Social History Review 55:2 (April 2018), 183-220.

Özcan, Azmi. Pan-Islamism: Indian Muslims, the Ottomans and Britain, 1877-1924. The Ottoman Empire and Its Heritage, vol. 12. Leiden: Brill, 1997.

Pernau, Margrit. "The Delhi Urdu Akhbar between Persian Akhbarat and English Newspapers." The Annual of Urdu Studies 18 (2003): 105-31.

—. "The Virtuous Individual and Social Reform: Debates among North Indian Urdu Speakers." In Civilizing Emotions: Concepts in Nineteenth-Century Asia and Europe, ed. Margrit Pernau, Helge Jordheim, and Orit Bashkin. Oxford: Oxford University Press, 2015.

— , and Yunus Jaffery. Information and the Public Sphere: Persian Newsletters from Mughal Delhi. Oxford: Oxford University Press, 2009.

Powell, Avrill. "Old Books in New Bindings: Ethics and Education in Colonial India." In Knowledge Production, Pedagogy, and Institutions in Colonial India, ed. Indra Sengupta and Daud Ali. Basingstoke: Palgrave Macmillan, 2011. 
Ray, Deeptanil, and Abhijit Gupta. "The Newspaper and the Periodical Press in Colonial India.” In Journalism and the Periodical Press in Nineteenth-Century Britain, ed. Joanne Shattock, 24562. Cambridge: Cambridge University Press, 2017.

Ray, Rajat Kanta. The Felt Community: Commonalty and Mentality before the Emergence of Indian Nationalism. New Delhi: Oxford University Press, 2003.

Renold, Leah. A Hindu Education: Early Years of the Banaras Hindu University. New Delhi: Oxford University Press, 2005.

Robinson, Francis. "Strategies of Authority in Muslim South Asia in the Nineteenth and Twentieth Centuries." Modern Asian Studies 47:1 (January 2013), 1-21.

Sharar, 'Abdulhalīm. Lucknow, the Last Phase of an Oriental Culture. UNESCO Collection of Representative Works. London: Elek, 1975.

Sharma, Rajendra Prasad. Pandit Balkrishna Bhatt. Hospital Road, Agra: Vinod Pustak Mandir, 1958.

Shaw, Graham. "Lithography v. Letter-Press in India, Part I: Lithography in Bombay." South Asia Library Notes and Queries 29 (1993): 1-11.

Singh, Mohinder. "Spectres of the West: Negotiating a Civilizational Figure in Hindi." In Civilizing Emotions: Concepts in Nineteenth-Century Asia and Europe, ed. Margrit Pernau, Helge Jordheim, and Orit Bashkin. Oxford: Oxford University Press, 2015.

Sonwalkar, Prasun. "Rammohun Roy's Idea of 'Public Good' in the Early Days of Journalism Ethics in India." In Media Ethics and Justice in the Age of Globalization, ed. S. Rao and H. Wasserman, 155-73. London: Palgrave Macmillan, 2015.

Stark, Ulrike. "Associational Culture and Civic Engagement in Colonial Lucknow." Indian Economic and Social History Review 48:1 (2011), 1-33.

- An Empire of Books: The Naval Kishore Press and the Diffusion of the Printed Word in Colonial India. Ranikhet: Permanent Black, 2007.

—. "Politics, Public Issues and the Promotion of Urdu Literature: Avadh Akhbar, the First Urdu Daily in Northern India." Annual of Urdu Studies 18:1 (2003), 66.

Stephens, Julia. "The Phantom Wahhabi: Liberalism and the Muslim Fanatic in Mid-Victorian India." Modern Asian Studies 47:1 (2013), 22-52.

Taylor, Miles. Empress: Queen Victoria and India. New Haven, Conn.: Yale University Press, 2018.

Vasunia, Phiroze. "Akbar's Dream: The Mughal Emperor in Nineteenth-Century Literature." In Regimes of Comparatism: Frameworks of Comparison in History, Religion and Anthropology, ed. Renaud Gagne, 284-317. Boston: Brill, 2018.

Warner, Michael. Publics and Counterpublics. New York: Zone Books, 2010.

\section{Notes}

- Leigh Denault is a historian of modern South Asia at Churchill College, University of Cambridge.

1 Hindi Pradip, 1 July 1878, in Selections from the Vernacular Newspapers (hereafter SVN), North-Western Provinces (hereafter NWP).

2 Sharma, Pandit Balkrishna Bhatt, 63-6.

3 Bhatnagar, The Rise and Growth of Hindi Journalism, 697.

4 Handa, History of Hindi Language and Literature, 305.
5 Bhatnagar, The Rise and Growth of Hindi Journalism, 478-9.

6 Dalmia, The Nationalization of Hindu Traditions.

7 Bayly, "Patrons and Politics," 53.

8 Bhatnagar, The Rise and Growth of Hindi Journalism, 222.

9 Gupta, Sexuality, Obscenity, Community, 330.

10 Bhatnagar, The Rise and Growth of Hindi Journalism, 479-80.

11 Bhatt's highly educated mother, Parvati Devi, had insisted that he attend the 
Yamuna Mission School so that he would be fluent in English, and he was educated in Sanskrit at the Pathshala school, and in Bengali, Persian, and English at home. Sharma, Pandit Balkrishna Bhatt.

12 Renold, A Hindu Education, 26-8.

13 Chandra, The Oppressive Present, 48.

14 Sharma, Pandit Balkrishna Bhatt. See the section on Hindi Pradip, 63-6. For a political biography of Bal Gangadar Tilak, see Guha, Makers of Modern India.

15 Freitag, Collective Action and Community.

16 Akhlaq is often translated as "ethics" or "morality," and twinned with works on $a d a b$ (treatises on behaviour), forming a body of literature of instruction for rulers on the correct management of household and state. Alam, The Languages of Political Islam, chap. 2.

17 Bayly, Recovering Liberties.

18 Mir, The Social Space of Language.

19 Gilmartin, "Rethinking the Public," 378-9.

20 Stark, "Associational Culture and Civic Engagement." Urdu publicists and intellectuals associated with the Jalsah-e Tahzib, as Stark explores, began to translate "public good" as rifah-I 'am.

21 Khanduri, Caricaturing Culture in India.

22 Gelvin and Green, Global Muslims.

23 Habermas, The Structural Transformation of the Public Sphere. On "counterpublics," see Fraser, "Rethinking the Public Sphere"; Warner, Publics and Counterpublics.

24 Bayly, Empire and Information; Kamra, The Indian Periodical Press; Bonea, The News of Empire.

25 Özcan, Pan-Islamism, chap. 2.

26 Bayly, Empire and Information.

27 Ibid., 343.

28 Kundu, "The Dramatic Performances Act of 1876."

29 On colonial legislation to control the press in nineteenth-century India see Kamra, The Indian Periodical Press, 89.
30 Banerjee, Becoming Imperial Citizens, 17.

31 Freitag, "Postscript"; Freitag, Collective Action and Community; Ingram, Scott, and Tareen, "What Is a Public?"

32 Frere, "The Means of Ascertaining Public Opinion."

33 Ghosh, "The Many Worlds of the Vernacular Book"; Moitra, "Reading Together."

34 Sharar, Lucknow, 107.

35 Birdwood, "The Native Press of India," 422.

36 Ghosh, "An Uncertain 'Coming of the Book," 23-55; Orsini, Print and Pleasure.

37 Orsini, "What Did They Mean by 'Public'?," 409-16.

38 Stanhope's portable iron hand-press prototype, invented in 1800 , provided a cheap, mobile, and reliable technology which underpinned the expansion of print. Green, "Persian Print and the Stanhope Revolution."

39 First introduced by the Portuguese, print did not take root until the combination of increased demand for news and entertainment and the arrival of lithography, both via East India Company and Iranian entrepreneurs. The first Muslim-run Urdu press in North India was established in 1819, in the independent Mughal successor-state of Awadh, but the coming of lithography in the 1830s led to an explosion of Persian and Urdu-script publications, with more than a dozen lithographic presses operating in its capital, Lucknow, alone by 1848 .

40 Pernau, "The Dehli Urdu Akhbar," 105; Pernau and Jaffery, Information and the Public Sphere.

41 Birdwood, "The Native Press of India."

42 Bayly, Recovering Liberties; Sonwalkar, "Rammohun Roy's Idea of 'Public Good."'

43 Ingram, Scott, and Tareen, "What Is a Public?"; Orsini, "What Did They Mean by 'Public'?"

44 Bayly, Recovering Liberties; Conrad, "Enlightenment in Global History." 
45 Hasan, "Forms of Civility."

46 Cohn, Colonialism and Its Forms of Knowledge. Cf. Bayly, Empire and Information.

47 See Orsini, The Hindi Public Sphere; Orsini, Print and Pleasure; Stark, An Empire of Books.

48 E.g., Chatterjee, The Nation and Its Fragments; Freitag, Collective Action and Community; Naregal, Language, Politics, Elites; Haynes, Rhetoric and Ritual in Colonial India; Gupta, Sexuality, Obscenity, Community.

49 Ingram, Scott, and Tareen, "What Is a Public?," 359.

50 Ibid., 363.

51 Bhattacharya, "Notes Towards a Conception of the Colonial Public," 143.

52 Majeed, "Narratives of Progress," 137-8.

53 Dubrow, Cosmopolitan Dreams.

54 Majeed, "Narratives of Progress."

55 Bhatnagar, The Rise and Growth of Hindi Journalism.

56 Bhattacharya, "Notes Towards a Conception of the Colonial Public," 141.

57 See Naregal, Language, Politics, Elites; Orsini, The Hindi Public Sphere; Stark, An Empire of Books.

58 Khanduri, Caricaturing Culture in India.

59 Dubrow, Cosmopolitan Dreams; Khanduri, Caricaturing Culture. On playfulness, see Orsini, Print and Pleasure.

60 On taxation in the 1870 s, see Das Gupta, Rise of an Indian Public.

61 Hindi Pradip, 1 July 1878, SVN NWP.

62 Lal, "Aurangzeb, Akbar."

63 Bayly, Recovering Liberties, 54.

64 Vasunia, "Akbar's Dream," 289.

65 Delhi Urdu Akhbar, 7 August 1853. Translated and excerpted in Pernau, "The Delhi Urdu Akhbar," 121.

66 "The Mughal and British Empires Compared," Hindoo Patriot, May-June 1854.

67 Ross, ed. Fakhr-i-Mudabbir, Ta'rikh-i Fakhr al-Din Mubarak Shah
[Introduction to the Shajara-Yi-Ansab], 13.

68 Hasan, "Forms of Civility."

69 Banerjee, The Mortal God, 53.

70 Akhlaq texts were divided into three parts: ethics, then management of the household, then politics. Most modern texts, including those published by the colonial state, continued this pattern. Powell, "Old Books in New Bindings," 211.

71 Pernau, "The Virtuous Individual," $170-5$.

72 Powell, "Old Books in New Bindings."

73 Ibid., 200.

74 Chap. 5-7 in Alam, The Languages of Political Islam.

75 Singh, "Spectres of the West."

76 Pernau, "The Virtuous Individual," 170.

77 Ibid., 175.

78 Gilmartin explores the concept of the 'extrapolitical' in Moin's work, see: "Imperial Sovereignty," 81. For Moin's broader argument, see: Moin, The Millennial Sovereign, chap. 6.

79 Gilmartin, "Imperial Sovereignty," 82.

80 Hindi Pradip, 1 June 1878, SVN NWP.

81 Nizam-ul Akhbar, 25 March 1878, SVN NWP.

82 Hindi Pradip, 1 July 1878, SVN NWP.

83 Blake, "Returning the Household," 221.

84 Ibid.

85 Ibid.

86 On Mandlik and Native Opinion, see Naregal, Language, Politics, Elites, 199.

87 "Lack of Sympathy between Ruler and Ruled," Native Opinion, 23 September 1873.

88 Nur-ul-Absar, 15 April 1878, SVN NWP.

89 Banerjee, Becoming Imperial Citizens, 52.

90 For a discussion of Harischandra and monarchism, see: Chandra, Oppressive Present, 28-9.

91 Taylor, Empress, 143.

92 Ibid., 144; See also the discussion of Harsichandra's politics in Dalmia, The Nationalization of Hindu Tradition. 
93 Hindi Pradip, 1 August 1878, SVN NWP.

94 Aydin, The Idea of the Muslim World, 7.

95 Awadh Akbar, 14 June 1878, SVN NWP.

96 Awadh Akbar, 14 June 1878, SVN NWP.

97 Sadharani, 14 April 1878, SVN Bengal.

98 Hindi Pradip, 1 July 1878, SVN NWP.

99 Benares Akhbar, 22 April 1875, SVN NWP.

100 Vrita Dhara, 8 April 1878, VNR NWP.

101 Ibid.

102 Bayly, Recovering Liberties, 28.

103 Sukanya Banerjee's reading prompted my rethinking of the Proclamation. Banerjee, Becoming Imperial Citizens, 22-3.

104 Barber, The Anthropology of Texts, 202.

105 Dalmia, The Nationalization of Hindu Traditions.

106 Natarajan, History of Indian Journalism, 55.

107 Stark, An Empire of Books; Ghosh, "An Uncertain 'Coming of the Book."”

108 Ray and Gupta, "The Newspaper and the Periodical Press."

109 Ibid.

110 Moin, The Millennial Sovereign, 205-6.

111 Metcalf, Moral Conduct and Authority; Robinson, "Strategies of Authority."

112 Cordell, "Reprinting, Circulation, and the Network Author," 417.

113 Ibid., 418.

114 Advertising had not yet emerged as a widespread source of funding Indian-language periodicals.

115 O'Sullivan, "Pan-Islamic Bonds"; Özcan, Pan-Islamism; Aydin, The Idea of the Muslim World.

116 Madras was excluded from the 1878 Vernacular Press Act, largely due to the belief that any seditious material was simply being reproduced from northern and western Indian papers.

117 Özcan, Pan-Islamism.
118 Shams-ul-Akhbar, 25 March 1878, SVN Madras.

119 O'Sullivan, "Pan-Islamic Bonds."

120 Awadh Akbar, 14 June 1878, SVN NWP.

121 Stark, An Empire of Books, 374-7.

122 Stark, "Politics, Public Issues," 76.

123 Mookerjee, Lucknow and the World of Sarshar, 102-33.

124 "Dream," Sadharani, 17 March 1878, SVN Bengal.

125 Howrah Hitkari, 24 March 1878, SVN Bengal.

126 Stark, An Empire of Books; Orsini, Print and Pleasure; Dubrow, Cosmopolitan Dreams.

127 Khanduri, Caricaturing Culture in India, 52.

128 Akhbar-i-Tamanni, 16 March 1878, SVN NWP.

129 Ibid.

130 Bhattacharya, "Notes Towards a Conception of the Colonial Public," 156.

131 Ibid.

132 Discussion in the Rast Goftar on 24 March 1878 accepted that some of the articles may have been actionable, but not all.

133 Sahachar, 29 April 1878, SVN Bengal.

134 Mohanty, Periodical Press and Colonial Modernity, 29.

135 Nasim-i-Jaunpur, 17 Aug 1875, SVN NWP.

136 Pratikar, 12 April 1878, SVN Bengal.

137 Chatterjee, The Black Hole of Empire, 120.

138 Dubrow, Cosmopolitan Dreams.

139 Certeau, "Reading as Poaching," 16576.

140 Chartier, The Order of Books, vii-ix, 2.

141 Certeau, "Reading as Poaching."

142 Chartier and Gonzalez, "Laborers and Voyagers."

143 Gilmartin, "Rethinking the Public," 373.

144 Bayly, "Religion, Liberalism and Empires." 